\title{
The Influence of Supervisor and Co-Worker Social Support Towards Resilient Self-Efficacy of Psychiatric Hospital Nurses
}

\author{
Tasia Puspa Sari ${ }^{1}$ Jenny Lukito Setiawan ${ }^{2}$ \\ ${ }^{1}$ Faculty of Psychology, University of Surabaya \\ ${ }^{2}$ Faculty of Psychology, Universitas Ciputra Surabaya \\ Submitted 28 March 2019 Accepted 27 May 2019 Published 20 April 2020
}

\begin{abstract}
The standard and complexity of nurse job tend to create heavy burden for nurses in performing nursing duties. The current study aimed to examine the influence of social support from supervisors and co-workers towards the resilient self-efficacy of psychiatric hospital nurses. The participants were 70 psychiatric hospital nurses in Surabaya. The study used Social Support Scale and Resilient Self-efficacy Scale. Multiple linear regression analysis showed that supervisor and co-worker support simultaneously had a significant influence on psychiatric hospital nurses' resilient self-efficacy ( $F=32.837$; $\mathrm{p}<0.05)$ with contribution of $35 \%\left(\mathrm{R}^{2}=0.3528\right)$. Hypothesis testing showed that when given separately, supervisor social support did not influence psychiatric hospital nurses' resilient self-efficacy $(\mathrm{r}=0.089 ; \mathrm{p}>0.05)$. However, co-worker social support significantly influenced psychiatric hospital nurses' resilient self-efficacy even when given separately $(\mathrm{r}=0.558 ; \mathrm{p}<0.05)$. This study concluded that compared with supervisor social support, co-worker social support significantly influenced psychiatric hospital nurses' resilient selfefficacy.
\end{abstract}

Keywords: co-worker social support, psychiatric hospital nurse, resilient self-efficacy, supervisor social support

Health is not everything, but anything without health is nothing. No one wants to suffer any illness if they can stay healthy. However in reality, the number of Indonesians who suffer from illness is relatively high. Former Health Minister, Nila Djuwita F. Moeloek, said 33\% of Indonesia's National Health Insurance (BPJS) expenditure went to pay the cost of patients' hospitalization (Maharani, 2015). Considering the high number of people suffering from diseases or illnesses,

\footnotetext{
${ }^{1}$ Address for correspondence: tasiapuspa31@gmail.com
}

hospitals' capacity as institutions that provide health services is much needed.

As a health care facility, hospital is expected to prioritize social functions in providing health services. The quality of services provided by hospital indicates its success in carrying out its function as health care provider. There are several issues related to quality of services in hospital, with human resources as the most dominant factor i.e., medical personnel (doctors and nurses) and non-medical personnel (Amelia, 2009).

Nurses have responsibility to provide consultation, care, education to patients, 
and also disease prevention (Kemppainen, Tossavainen, \& Turunen, 2012). Due to this, nurses have an important role to deliver good quality services to patients based on biological, psychological, social, and spiritual approaches. Nursing service runs 24 hours a day. The quality of service provided must meet the standards and criteria of nursing profession to fulfill patient expectations (Amelia, 2009).

Quite the contrary, not all nursing services have met expectations. People complain about the quality of nursing services. Some others are also dissatisfied and disappointed with services in certain hospitals. The complaint concerns with rude and unfriendly attitudes of nurses to patient's family. In addition, the long waiting time to receive health services is also widely criticized by citizens.

The standard and complexity of nurse job tend to create heavy burden for nurses in performing nursing duties, thus affecting the quality of nursing services delivered by nurses. Sarafino and Smith (2011) said that nurse has high and pressing work demands. Nurses' work schedule is tight, demanding nurses to be ready to work at any time. Nurses are responsible for patients' health and safety. With big responsibility comes big consequences if there was any mistake in nursing services. Other factors that contribute to nurse workload generally are patient's unpredictable condition, excessive working hours, the desire to excel in work performance, high work demands, also must do nursing care documentation (Munandar, 2014).

Nurses in mental health unit are part of general nurses but focusing on providing nursing services to patients with mental health issues and generally working in psychiatric hospitals. There is a fundamental difference between general nurses and mental health nurses. General nurse usually pays more attention to patients' physical condition even though their spiritual state is not neglected, whereas mental health nurse pays more attention to patients' spiritual state without ignoring their physical condition (Yosep, 2009).

A study conducted by Nugroho, Andrian, and Marselius (2012) showed that limited workforce also affects mental health nurse performance. Nurse on day shift duty feels that intern nurses help their workload whilst nurse on night shift duty is prone to feel overwhelmed due to less number of nurses on duty. Nurse on night shift duty also often has to deal with patients who experience anxiety problems in the middle of the night. The relatively monotonous nursing job causes some nurses in psychiatric hospitals to experience boredom with work and feel that they cannot develop their potentials.

Nurse in psychiatric hospital also encounters patients with mental illness who have unstable conditions. Patients might be silent but all of sudden can behave hyperactively and aggressively, endangering themselves and others (Hasan, 2017). Due to this condition, patients in psychiatric hospitals require special treatment.

Generally, it is difficult to communicate with mental health patients because they tend to remain mute, however all of sudden patients can be difficult to contain (Yosep, 2009). This situation requires mental health nurse to have good selfregulation and take appropriate action so that patients do not injure themselves or anyone, including the nurse. If mental health nurse does not have self-regulation and cannot act properly, it can cause work stress on mental health nurse. 
Attending to mental health patients creates different kind of work pressure compared to attending patients with physical illness because the problems experienced by mental health patients are not visible unlike physical illness. In addition, nurse in psychiatric hospital encounters challenges in dealing with patients' cognitive, language, and behavioral discordance (Ahanchian, Meshkinyazd, \& Soudmand, 2015). Most mental health patients are unable to disclose their problems and sometimes they reveal contradictive information (Amelia, 2009).

Constant pressure and heavy workload will have negative influence on nurse, i.e., nurse behavior that is not in accordance with patient expectations. Based on interview with a psychologist at Psychiatric Hospital X Surabaya, it can be concluded that when nurse feels they have high workload, they cannot attend to patients optimally and becoming more impatient.

Professions related to public health sector are prone to workplace stress, including nurses (Lailani, 2012). High work demands might cause nurse to experience higher stress level. Research from National Institute for Occupational Safety and Health (NIOSH) established nurse as a profession with high stress risk (Prihatini, 2007). Every day, psychiatric hospital nurse have to handle mental health patients with distinctive or even peculiar behaviors. Mental health patient's behavior can affect the psychological condition of mental health nurse (Juwita, Sedyowinarso, \& Nurjannah, 2008). Study conducted by Ilmi (2002) showed that there are six stressors for nurses including excessive workload, multiple roles, conflict with other employees, unsupportive work relations, absence of performance feedback, and role conflict.
Every nurse has their own way to overcome work challenges and avoid workplace stress. Nurse must have resilient self-efficacy or the confidence in their ability to persevere despite facing difficult situations at work and experience personal growth from any problem

According to Bandura (1997), selfefficacy is individual belief to achieve something in certain situation. Self-efficacy will affect individual's cognition, feeling, behavior, and decision making in life. Grotberg (1995) defined resilience as the ability of individual to confront, to solve, to become resilient and to grow from their difficult situations. Individual with resilience knows how to turn stressful events into opportunities to develop themselves (Utami \& Helmi, 2017). It can be concluded that resilient self-efficacy is individual belief to confront and overcome difficult situations, while also experiencing personal growth at the same time. Resilient self-efficacy is an important factor that contributes to optimism and associated with more positive attitude in facing various challenges (Reyes, Andrusyszyn, Iwasiw, Forchuk, \& Mould, 2015).

There are several factors related to resilient self-efficacy in individual. According to Bandura (1997), these four factors are mastery experience, vicarious experience, verbal persuasion, and psychological and affective states. Researchers surmised that social support can affect resilient self-efficacy in individual.

Kim, Sherman, and Taylor (2014) defined social support as the perception or experience in which individual is cared for, esteemed, and becoming a part of supportive social network. Social support compels individual to feel cared for and loved thus helps individual to resolve their problems. Individual who perceives high social support is more successful in coping 
with stress than individual who perceives less social support (Kim, Sherman, \& Taylor, 2014).

Social support encompasses emotional and informational supports (Sarafino \& Smith, 2011). Emotional support can be provided to individual as verbal persuasion, e.g., attention, praise, empathy, and positive encouragement to increase individual's self-esteem as well as physiological and affective states. Perceived verbal persuasion from emotional support can improve individual's capability (Setiawan, 2017). Informational support can be provided to individual as information, advice, recommendation, and proposition to help someone overcoming their problems. Information can be obtained from individual's social network, including someone who might have successfully resolved similar problem. Vicarious experience can create opportunities from individuals to learn from others' experiences.

Social support encourages individual to be able to overcome their problems. Individual's accomplishment in coping with stress and difficult situations will be one's mastery experience. This accomplishment can increase individual resilient self-efficacy.

According to Sarafino and Smith (2011), social support is influenced by support providers. The most effective social support for individual with high work demands is obtained from their supervisors or co-workers (Lailani, 2012). Individual finds it easier to get relevant information and assistance about their problems from supervisors or co-workers.

Previous study on company employees showed that social support from workplace can reduce negative feelings about their work (Septriari \& Wintriarsi, 2014). Reducing negative feelings causes individual to feel more emotionally comfortable which will influence their confidence in carrying out their duties. Supervisors and co-workers can be sources of social support at work. Study conducted by Santoso and Setiawan (2018) showed that social support has significant role towards special teachers resilient selfefficacy, focusing on social support from family, supervisors, and co-workers. However the present study focused on social support from supervisors and co-workers.

Individual resilient self-efficacy increases when they received social support (Herrman et al., 2016). In work context, social support is influenced by organizational culture (Gauthier \& Marchand, 2016). Organizational culture is embedded in values, beliefs, and norms as guideline for organization member behavior (Chang \& Lu, 2007). Each organization has its own culture. Researchers surmised that organization culture differences will produce different kinds of interactions in organization which also creates differences in pattern of social support. Thus, it will affect the formation of resilient selfefficacy of an individual. The result of this study might be different from previous studies considering the differences of organizational culture experienced by psychiatric hospital nurses, company employees, and special needs teachers. Researchers were interested to see the role of supervisor and co-worker social support towards resilient self-efficacy of psychiatric hospital nurses.

The urgency of study about resilient self-efficacy is because its influence to quality nursing services of nurse. Nurse can deliver optimum services and fulfill community expectations when they experience psychological well-being. Resilient self-efficacy in nurse is expected to contribute in providing better nursing services. The aim of this study was to 
conduct empirical test on the role of supervisor and co-worker social support towards resilient self-efficacy of psychiatric hospital nurses. The present study proposed three hypotheses. The major hypothesis was supervisor and co-worker social support simultaneously had significant influence towards resilient selfefficacy of psychiatric hospital nurses. First minor hypothesis, supervisor social support had significant role towards resilient self-efficacy of psychiatric hospital nurses. Second minor hypothesis, coworker social support had significant role towards resilient self-efficacy of psychiatric hospital nurses.

\section{Methods}

This study used three variables: supervisor social support and co-worker social support as independent variables, and resilient self-efficacy as dependent variable. Participants were 70 psychiatric hospital nurses in Surabaya $(54.3 \%$ male and $45.7 \%$ female). The majority of nurses were in the age range of 21-40 years old $(74.4 \%)$. The majority of nurses had more than 5 years of work experience with composition of $24.3 \%$ had $1-3$ years of work experience, $14.3 \%$ had $3-5$ years of working experience, and $61.4 \%$ had more than 5 years of working experience.

This study used supervisor and coworker Social Support Scale (Kim, 2013b) and also Resilient of Efficacy Scale (Kim, 2013a). The scales were adapted and translated to Indonesian language by linguist. The scales were modified by researchers to adjust the research variables.

Social Support Scale developed by Kim (2013b) had been modified by researchers. The sources of social support were altered to match the research variables, namely supervisors and co- workers. The scale consisted of twelve items related to social support obtained by participants from supervisors (six items) and co-workers (six items). Participants were asked to fill the scale by giving score from 1 to 7 . The greater social support felt by participants, the higher the score given (closer to 7) whereas the lesser social support felt by participants, the lower the score given (closer to 1).

Resilient Self-Efficacy scale described participants' resilient self-efficacy ability. The scale consisted of six items. Participants were asked to rate between 1 and 7. The higher participants' ability to perform tasks according to the item statements, the higher the score given (closer to 7). Higher score indicated higher participants' resilient self-efficacy.

Based on the result of corrected itemtotal correlation, it could be concluded that all items on the scales had met the correlation coefficient criteria $\geq 0.3$ and $p<$ 0.05 . In addition, the scales used in this study had good reliability. Reliability estimation results can be seen in Table 1 .

Table 1.

Reliability Estimation Results

\begin{tabular}{lr}
\hline \multicolumn{1}{c}{ Scale } & $\begin{array}{c}\text { Cronbach's } \\
\text { Alpha }\end{array}$ \\
\hline Supervisor' Social Support & 0.978 \\
Co-worker Social Support & 0.974 \\
Resilient Self-efficacy & 0.898 \\
\hline
\end{tabular}

Hypothesis testing was done using multiple regression analysis to determine the role of supervisor, and co-worker social support towards resilient selfefficacy of psychiatric hospital nurses.

\section{Result}

Descriptive statistical analysis of supervisor and co-worker social support 
and resilient self-efficacy is presented in Table 2.

Hypothesis testing with regression analysis showed that the major hypothesis (supervisor and co-worker social support simultaneously had significant role on resilient self-efficacy) and the second minor hypothesis (co-worker social support had significant role on resilient self-efficacy) were accepted, while the first minor hypothesis (supervisor social support had significant role on resilient self-efficacy) was rejected. Statistical analysis indicated significant role of supervisor and co-worker social support towards resilient self-efficacy $\left(\mathrm{R}=0.594 ; \mathrm{R}^{2}\right.$ $=0.3528 ; \mathrm{F}=32.837 ; \mathrm{p}<0.05$ )

\section{Discussion}

Based on hypotheses testing results, it could be concluded that supervisor and co-worker social support simultaneously had significant role on resilient selfefficacy of psychiatric hospital nurses. Supervisor and co-worker social support contributed to resilient self-efficacy of psychiatric hospital nurses by $35 \%$ $\left(\mathrm{R}^{2}=0.3528\right)$. The minor hypotheses testing results indicated that supervisor social support did not have significant role in resilient self-efficacy if given separately. Meanwhile, co-worker social support still had significant role towards resilient selfefficacy of psychiatric hospital nurses if given separately.
Lailani (2012) stated that social support obtained by nurse can provide psychological strength to overcome their problems. Nurse who believes in their ability to complete complex tasks and also receives social support from supervisors, co-workers, and family is able to avoid burnout.

The first minor hypothesis testing result showed that supervisor social support, if given separately, did not have significant role on resilient self-efficacy. However, this does not mean that nurses did not get any form of social support from their supervisors. Most nurses perceived to earn "high" and "very high" supervisor social support, but it did not affect their resilient self-efficacy.

Possible reason for the result of first minor hypothesis testing was big power distance in organization. This is consistent with Hofstede's research (in Hofstede Insight, 2019) discovered that power distance dimension in Indonesia showed the highest score (78) compared to other dimensions i.e., individualism (14), masculinity (46), uncertainty avoidance (48), long term orientation (62), and indulgence (38). Most organization cultures in Indonesia tend to depend on hierarchy, unequal rights between power holders and non-power holders, centralized management control, and employees expectation for direction from leaders (Hofstede in Hofstede Insight, 2019).

Table 2

Descriptive Statistic Analysis of Supervisor Social Support, Co-worker Social Support, and Resilient Self-Efficacy

\begin{tabular}{lcc}
\hline \multicolumn{1}{c}{ Variable } & Mean & Standard Deviation \\
\hline Supervisor Social Support & 5.00 & 1.177 \\
Co-worker Social Support & 5.60 & 0.922 \\
Resilient self-efficacy & 5.56 & 0.789 \\
\hline
\end{tabular}


Table 3.

Minor Hypotheses Testing

\begin{tabular}{cccccc}
\hline \multirow{2}{*}{ Model } & \multicolumn{2}{c}{$\begin{array}{c}\text { Unstandardized } \\
\text { Coefficients }\end{array}$} & Standardized Coefficients & \multirow{2}{*}{ Sig. } & \\
\cline { 2 - 5 } & B & Std. Error & Beta & & \\
\hline Supervisor Social Support & 0.050 & 0.690 & 0.750 & 0.729 & 0.468 \\
Co-worker Social Support & 0.485 & 0.088 & 0.567 & 5.508 & 0.000 \\
\hline
\end{tabular}

Power distance describes inequality between power holders and non-power holders at work place (Hofstede \& Bond, 1988). This condition leads to one-way communication between supervisors and subordinates, which causes supervisors to have difficulty in building subordinates' self-esteem, resulting in lower work readiness. Individual who grows in organization with power distance tends to conform to their supervisors' decisions and actions (Zagladi, 2017). Generally, they will carry out their duties according to order from their supervisors without question or discussion. They also try not to violate the order as much as possible.

Another possible cause of no significant correlation between supervisor social support and resilient self-efficacy is because some nurses did not perceive their supervisors as significant people in their lives. According to Armia (2002), power distance tends to induce centralized decision making and autocratic leadership style. Relationship between supervisors and nurses tends to be rigid which makes it difficult to establish two-way communication and emotional closeness. Thus, nurses may consider their supervisors as the secondary option to help resolving their problem.

On the other hand, if social co-worker social support was provided separately, there was significant influence towards resilient self-efficacy of psychiatric hospital nurses. Different form of relationship between nurse and sources of support will have different effects (Santoso \& Setiawan, 2018). It can be concluded that co-workers become valuable people for nurses when experiencing problems. Co-workers are more approachable for discussion about work problems. Relationships established between nurses are more flexible compared to supervisors. Based on interviews with three psychiatric hospital nurses, co-workers are willing to listen to their fellow nurses' work or personal problems. This is because fellow nurses experience relatively similar work condition. Almasitoh (2011) explained when coworkers can provide mutual support, there will be a situation where camaraderie and cooperation co-exist which leads to gratifying workplace environment. Coworker social support is able to reduce stress at work due to mutual understanding about the sources of stress at work.

Based on the explanation above, it can be concluded that co-worker social support has significant role towards resilient self-efficacy of psychiatric hospital nurses compared to supervisor social support. The conclusion of this study is different with Santoso and Setiawan (2018) findings which showed that supervisors played significant role towards resilient self-efficacy of special needs teachers. Supervisors had a role in providing informational and emotional supports which formed closeness between supervisors and special need teachers. The absence of emotional closeness between supervisors and psychiatric hospital 
nurses might be the reason of distance in supervisors and nurses relationship. This is related to psychological acceptance of provided social support.

Study conducted by Setiawan (2011) explained that individual tends to handle their own problems before making decision to ask others for assistance. Setiawan (2011) also described factors that influence individual in seeking assistance are personal quality, recognition of potential helper, helper's ability, helper social role, ease of seeing potential helper, and guarantee of confidentiality. However in the present study, the relationship between supervisors and nurses which tend to be rigid and lacked of emotional closeness allegedly affecting nurses intention in asking for help from their supervisors. This finding aligned with study by Setiawan (2011) that one of the main factors influencing individual's decision to seek help is the closeness between individual and potential helpers.

Nurses chose co-workers as potential people who were able to help solve their problems because co-workers fulfill several criteria that encourage nurses to ask for help. Fellow nurses tend to know each other better and have tighter bond compared with supervisors, considering they work together nearly every day attending patients. Relationship between nurses is more flexible than with supervisors.

The results of this study indicated that co-worker social support for nurses had significant role towards resilient selfefficacy of psychiatric hospital nurses compared with supervisor social support. Co-worker social support is related to nurses' confidence in their ability to overcome difficult situations related to work. Data analysis showed that effective contribution of supervisor and co-worker social support simultaneously towards resilient self-efficacy was 35\%. It implied that the remaining $65 \%$ variance was determined by other factors. Researchers presumed that there were several other factors that contribute towards resilient self-efficacy of psychiatric hospital nurses, i.e., sex and years of service.

Sex. According to Rinaldi (2010), there is a difference between resilience in men and women. Men tend to choose problem solving approach and have optimistic attitude compared to women. Women tend to display helplessness compared to men. Optimistic attitude in encountering difficulties indicates that individual has confidence to solve those difficulties.

Years of service. According to Kurniawati (2014), long years of service cause employees to feel at ease and attached to the company because they have been able to adapt to work environment in relatively long time so that they feel comfortable with their job. Individual with longer years of service has more work-related experiences and tend to have resolved more demands and problems successfully compared to individual who starts working later. Mastery experience in resolving demands and problems in workplace will boost individual's confidence in their own ability to solve subsequent work challenges.

\section{Conclusion}

This study showed that supervisor and coworker social support simultaneously had significant role towards resilient selfefficacy of psychiatric hospital nurses. The higher the social support received by nurse from both sources, the higher resilient self-efficacy of psychiatric hospital nurse. Supervisor and co-worker social support contributed $35 \%$ towards 
resilient self-efficacy. Partially, social support from co-workers had significant role towards resilient self-efficacy. Conversely, social support from supervisors did not have significant role towards resilient self-efficacy if provided partially. Thus, it can be concluded that co-worker social support had significant role towards resilient self-efficacy of psychiatric hospital nurses compared to supervisor social support.

\section{Suggestion}

Because of significant role co-worker social support towards resilient self-efficacy, researchers suggested co-workers to increase social support towards fellow colleagues. Openness among nurses improves social interactions, including sharing difficulties experienced at work. Co-workers can provide suitable social support because they also experience similar situations. The role of co-workers is expected to increase nurses' selfconfidence in overcoming work problems.

Meanwhile, considering there was no significant role of supervisor social support towards resilient self-efficacy, researchers suggested that supervisors enhance horizontal relation with subordinates through mentoring, coaching, or gathering to establish emotional closeness. Even though nurses perceived high supervisor social support, apparently it did not affect resilient self-efficacy. Individual acceptance towards psychological support might be the cause. Nurses did not consider supervisors as significant people in their lives to help overcoming work problems.

\section{References}

Ahanchian M. R., Meshkinyazd, A., \& Soudmand, P. (2015). Nurses burnout in psychiatric wards. Journal of Fundamentals of Mental Health, 17(5), 260-264.

Almasitoh, U. H. (2011). Stres kerja ditinjau dari konflik peran ganda dan dukungan sosial pada perawat. Jurnal Psikologi Islam, 8(1), 63-82.

Armia, C. (2002). Pengaruh budaya terhadap efektivitas organisasi: Dimensi budaya Hofstede. JAAI, 6(1), 103-117.

Amelia, R. (2009). Pengaruh motivasi berprestasi terhadap kinerja perawat dalam asuhan keperawatan pasien gangguan jiwa di Rumah Sakit Jiwa Daerah Provinsi Sumatera Utara, Medan. Majalah Kedokteran Nusantara, 42(1). 8-13.

Bandura, A. (1997). Self-efficacy in changing societies. Cambridge, UK: Cambridge University Press.

Chang, K., \& Lu, L. (2007). Characteristic of organizational culture, stressor, and wellbeing: The case of Taiwanese organizations. Journal of Managerial Psychology, 22(6), 549-568. doi: $\underline{10.1108 / 02683940710778431}$

Gauthier, J. D., \& Marchand, A. (2016). Does organizational culture play a role in the development of psychological distress?. The International Journal of Human Resource Management, 29(12), 130. doi: $10.1080 / 09585192.2016 .1216874$

Grotberg, E. H. (1995). A guide to promoting resiliency in children: Strengthening the human spirit. Early childhood development: Practice and reflection, 8. Retrieved from https://bibalex.org/baifa/Attachment/D ocuments/115519.pdf

Hasan, A. A. (2017). Work stress, coping strategies and level of depression among nurses working in mental hospital in Port-Said City. International Archives of Nursing and Health Care, 
3(2), $\quad 1-10 . \quad$ doi: $\quad \underline{10.23937 / 2469-}$ $\underline{5823 / 1510068}$

Herrman, H., Stewart, D, Granados, N. D., Berger, E. L., Jackson, B., \& Yuen, T. (2011). What is resilience?. The Canadian Journal of Psychiatry, 56(5), 258-265. doi: $10.1177 / 070674371105600$ $\underline{504}$

Hofstede, G., \& Bond, M. H. (1988). The Confucius connection: from cultural roots to economic growth. Organizational Dynamics, 16(4), 5-21. doi: $\underline{10.1016 / 0090-2616(88) 90009-5}$

Hofstede Insight. (2019). Country comparison: What about Indonesia?. Retrieved from https://www.hofstedeinsights.com/country-

comparison/indonesia/ Ilmi, B. (2002). Pengaruh stres kerja terhadap prestasi kerja dan identifikasi manajemen stres yang digunakan perawat di ruang inap RSUD Ulin Banjarmasin. (Unpublished master's thesis). Department of Health Policy Administration, Universitas Airlangga, Surabaya

Juwita, Sedyowinarso, M., \& Nurjannah, I. (2008). Faktor-faktor yang memengaruhi tingkat stres kerja perawat psikiatri di Rumah Sakit Jiwa Provinsi Kepulauan Bangka Belitung. Jurnal Ilmu Keperawatan, 3(3), 185-192.

Kemppainen, V., Tossavainen, K., \& Turunen, H. (2012). Nurse's roles in health promotion practice: an integrative review. Health Promotion International, 28(4), 490-501. doi: 10.1093/heapro/das034

Kim, H. S., Sherman, D. K., \& Taylor, S. E. (2014). Culture and social support. American Psychologist, 63(6), 518-526. doi: $\underline{10.1037 / 0003-066 x}$

Kim, U. (2013a). Resilience of efficacy scale. Unpublished manuscript. Korea:
Department of Business

Administration, Inha University.

Kim, U. (2013b). Social support scale. Unpublished manuscript. Korea: Department of Business Administration, Inha University.

Kurniawati, I. D. (2014). Masa kerja dengan job engangement pada karyawan. Jurnal Ilmiah Psikologi Terapan, 2(2), 311-324.

Lailani, F. (2012). Burnout pada perawat ditinjau dari efikasi diri dan dukungan sosial. Talenta Psikologi, 1(1), 68-75.

Maharani, D. (2015). Kata Menteri Kesehatan, masyarakat Indonesia lebih banyak yang sakit ketimbang sehat. Kompas.com. Retrieved from https://lifestyle.kompas.com/read/2015 12/29/174942723/Menkes.Masyarakat. Lebih.Banyak.yang.Sakit.daripada.Seh at

Munandar, A. S. (2014). Psikologi industri dan organisasi. Jakarta: UI Press.

Nugroho, A. S., Andrian, \& Marselius. (2012). Studi deskriptif burnout dan coping stres pada perawat di ruang inap Rumah Sakit Jiwa Menur Surabaya. Jurnal Ilmiah Mahasiswa Universitas Surabaya, 1(1), 1-6.

Prihatini, L. D. (2007). Analisis hubungan beban kerja dengan stress kerja perawat di tiap ruang rawat inap RSUD Sidikalang. (Unpublished master's thesis). Masters Program in Public Health Sciences, Universitas Sumatera Utara, Medan.

Reyes, A. T., Andrusyszyn, M. A., Iwasiw, C., Forchuk, C., \& Mould, Y. B. (2015). Resilience in nursing education: An integrative review. Journal of Nursing Education, 54(8), 438-444. doi: $\underline{10.3928 / 01484834-20150717-03}$ 
Rinaldi. (2010). Resiliensi pada masyarakat Kota Padang ditinjau dari jenis kelamin. Jurnal Psikologi, 3(2), 99-105.

Santoso, E., \& Setiawan, J. L. (2018). Peran dukungan sosial keluarga, atasan, dan rekan kerja terhadap resilient selfefficacy guru sekolah luar biasa. Jurnal Psikologi, 45(1), 27-39.

Sarafino, E. P, \& Smith, T. W. (2011). Health psychology: Biopsychosocial interactions (ed.7). New York: John Wiley \& Sons, Inc.

Septiari, E. D., \& Wintriarsi, D. (2014). Pengaruh dan konsekuensi work-family enrichment. Jurnal Manajemen 4(1), 2034.

Setiawan, J. L. (2011). Stages in the helpseeking decision-making process and factors involved. Anima, Indonesian Psychological Journal, 27(1), 34-40.

Setiawan, J. L. (2017). Building entrepreneurial children: Mengembangkan karakter entrepreneur anak melalui kualitas pernikahan orangtua. Surabaya: Penerbit Universitas Ciputra.

Utami, C. T., \& Helmi, A. F. (2017). Selfefficacy dan resiliensi: Sebuah tinjauan meta-analisis. Buletin Psikologi, 25(1), 54-65. doi: 10.22146/buletinpsikologi. $\underline{18419}$

Yosep, I. (2009). Keperawatan jiwa (ed.2). Bandung: Refika Aditama.

Zagladi, A. N. (2017). Power distance as a national culture observed in organizational scope. Journal of Management and Marketing Review, 2(3), 123-127. 